\title{
Effect of Palpable Udder Defects on Milk Yield, Somatic Cell Count, and Milk Composition in Non-Dairy Ewes
}

\author{
Mandefrot M. Zeleke ${ }^{1,2, *}$, Paul R. Kenyon ${ }^{3}$, Kate J. Flay ${ }^{4}{ }^{(}$, Danielle Aberdein ${ }^{1}$, Sarah J. Pain ${ }^{3}$, \\ Sam W. Peterson ${ }^{3}$ and Anne L. Ridler ${ }^{1}$ \\ 1 School of Veterinary Science, Massey University, Private Bag 11222, 4410 Palmerston North, New Zealand; \\ D.Aberdein@massey.ac.nz (D.A.); a.l.ridler@massey.ac.nz (A.L.R.) \\ 2 School of Veterinary Medicine, Wolaita Sodo University, Wolaita Sodo P.O. Box 138, Ethiopia \\ 3 School of Agriculture and Environment, Massey University, Private Bag 11222, \\ 4410 Palmerston North, New Zealand; p.r.kenyon@massey.ac.nz (P.R.K.); S.J.Pain@massey.ac.nz (S.J.P.); \\ S.Peterson@massey.ac.nz (S.W.P.) \\ 4 Department of Veterinary Clinical Sciences, City University of Hong Kong, Kowloon, \\ Hong Kong 999077, China; kateflay@cityu.edu.hk \\ * Correspondence: M.Meaza.zeleke@massey.ac.nz
}

check for updates

Citation: Zeleke, M.M.; Kenyon, P.R.; Flay, K.J.; Aberdein, D.; Pain, S.J.; Peterson, S.W.; Ridler, A.L. Effect of Palpable Udder Defects on Milk Yield, Somatic Cell Count, and Milk Composition in Non-Dairy Ewes. Animals 2021, 11, 2831. https:// doi.org/10.3390/ani11102831

Academic Editors: Luca Turini and Fabrizio Bertelloni

Received: 19 August 2021

Accepted: 23 September 2021

Published: 28 September 2021

Publisher's Note: MDPI stays neutral with regard to jurisdictional claims in published maps and institutional affiliations.

Copyright: (c) 2021 by the authors. Licensee MDPI, Basel, Switzerland. This article is an open access article distributed under the terms and conditions of the Creative Commons Attribution (CC BY) license (https:// creativecommons.org/licenses/by/ $4.0 /)$.
Simple Summary: The occurrence of udder defects in ewes impacts the productive lifespan of the affected ewe and reduces their lamb production. This study investigated the effects of palpable udder defects on milk yield and milk composition in Romney ewes. The findings showed that the effect of udder-half defects on udder-half milk yield was substantial; however, there was no difference in individual (whole udder) ewe milk production between ewes with one udder-half defective and both normal udder-halves. This was due to a compensatory increase in milk production of the normal udder half when the other udder half was defective, with the exception being ewes that retained the defects for several weeks. No notable difference in milk composition was observed between defective and normal udder halves, except for solids non-fat (SNF). This study shows that udder defects affect milk production in non-dairy ewes, highlighting the potential effects on lamb production.

Abstract: In non-dairy ewes, udder defects hinder the survival and weight gain of their pre-weaned lambs. The objectives of this study were to determine the effects of palpable udder defects on milk yield, somatic cell count (SCC), and milk composition in non-dairy Romney ewes. Ewes with a history of udder defects or normal udders were selected for the study. Of a total of 48 ewes that lambed, 30 ewes reared at least one lamb, and were milked six times, once weekly, for the first six weeks of lactation. Udder halves were palpated and scored at each milking event. Multivariate linear mixed models examined the impacts of udder defects on udder-half and whole-udder milk yield, SCC, and milk composition (fat, protein, lactose, total solids, and solids non-fat (SNF)). Across the six examinations, $24.7 \%$ of the total 352 udder-half examinations were observed to be defective. Udder halves that were defective at least once produced on average $57.9 \%$ less $(p<0.05)$ milk than normal udder halves, while normal udder halves with a contralateral defective half yielded 33.5\% more $(p<0.05)$ milk than normal udder halves. Successive occurrence of both hard and lump udder defect categories in an udder-half, udder defect detection early in lactation, and a high frequency of udder defect detection were all associated with udder-half milk yield loss $(p<0.05)$. At the whole-udder level, no differences in milk yield $(p>0.05)$ were observed between those with one udder-half defective and both normal udder-halves. However, udders in which one udder half was categorised as hard but progressed to lump and remained as lump until 42 days of lactation produced less $(p<0.05)$ milk compared with normal udders. With the exception of SNF, there were no significant associations ( $p>0.05$ ) between milk composition parameters and udder defect. Overall, these findings emphasise the importance of udder health in non-dairy ewes and the potential effect of udder defects on their lambs.

Keywords: hard udder; lactation; milk composition; milk yield; somatic cell count; udder health 


\section{Introduction}

Various udder defects including mastitis have been reported in both dairy and nondairy ewes [1,2]. Clinical presentations of these defects include signs of inflammation, abnormal secretion, abscesses, lumps, nodules, diffuse hardness, and cysts [1-3]. Udder defects cause mild to serious damage to the mammary gland in ewes [4-6]. This damage can hinder the synthetic capacity of epithelial cells and/or increase the permeability of blood components into the milk $[7,8]$. The occurrence and impact of these defects varies greatly depending on many factors, such as the individual animal, causative agent, severity of infection, management factors, production systems, genetics/breed, udder morphology, production level, and whether both or single udder-halves are involved [9-11]. Globally, the prevalence of udder defects in non-dairy ewes ranges from 0 to $10.9 \%[2,12-16]$. The prevalence of udder defects in New Zealand is up to $7 \%$ [3,17-21].

Udder defects in dairy ewes can be detected more frequently compared to non-dairy ewes because farmers check the udder during regular daily milking events [22]. In nondairy ewes, udder defects are usually only identified at weaning or prior to mating, when farmers are selecting ewes for the next breeding season [2]. However, a condition described as "hard udder" has been observed during early lactation [23], while the prevalence of clinical mastitis has been reported to be higher shortly after lambing [24], which is a time when most farmers would not be checking the udders of non-dairy breed ewes in outdoor lambing systems.

Clinical and sub-clinical mastitis have a significantly negative impact on milk yield in ewes [4,24-27]. In dairy ewes, studies on the effect of mastitis on milk yield and composition have been undertaken for the purposes of quantifying milk losses and assessing milk quality for cheese production $[7,28]$. In contrast, in non-dairy ewes, the focus of studies investigating mastitis $[14,27,29]$ or palpable udder defects $[1,15,18]$ have been to investigate growth rates and survival of pre-weaned lambs. Mastitis decreases milk yield and alters milk composition, including protein, fat, and lactose $[7,18,30]$. Lactose concentration decreases in mastitic (subclinical and clinical) ewes because of tissue damage, which interferes with its synthesis [28] and osmotic regulation role, which accentuates the decrease [27]. Changes in milk fat and protein levels vary depending on the volume of milk loss or the dilution effect during mastitis [31,32].

An individual ewe whole-udder assessment approach has been used to diagnose mastitis, quantify milk yield loss, and assess milk composition for both dairy and non-dairy ewes $[5,28,33]$. However, due to the anatomic, functional, and infection independency of the two udder-halves, and the compensatory effects in both unilateral and bilateral infection, assessment of the whole-udder has been associated with huge individual variation $[11,25,34]$. Hence, determining milk losses due to mammary infection is better studied by assessment of individual udder-halves [27].

In non-dairy ewes, there are a limited number of studies on the impact of udder defects on milk yield despite the potential serious consequences to lamb growth and survival to weaning and subsequent culling of affected ewes $[1,15,18]$. "Hard udder", a diffuse hard consistency of the udder occurring at or shortly after parturition, has been reported to result in udders that appear to be full of milk but fail to express milk after lambing $[20,23]$. Hard udders have been associated with teat cord (hard core) formation, which may prevent milk removal [19]. Ewes whose mammary glands contain lumps have been associated with decreased body weight gain in pre-weaned lambs [35]. The presence of mammary glands with lumps is also a reported reason for culling of ewes, as it is assumed they have decreased milk production [15,19] and reduced overall productivity [36]. Moreover, milk samples collected from ewe udders with defects including nodules, lumps, diffuse hardness, and abscesses were reported to contain clots and flakes, serous and purulent fluid, and blood-stained secretions [2].

To the authors' knowledge, no previous studies have assessed the effect of palpable udder defects on milk yield and composition in either dairy or non-dairy ewes. Therefore, the objectives of this manuscript were to quantify the effects of palpable udder defects 
on udder-half and whole-udder milk yield, somatic cell count, and milk composition in mixed-age non-dairy breed (Romney) ewes. It was hypothesized that udders with palpable defects would show decreased milk yield and altered milk composition compared with normal udders.

\section{Materials and Methods}

\subsection{Ewe Selection}

Eighty commercial ewes aged five to six years were selected from Massey University's Riverside farm, Wairarapa, New Zealand, based on udder and teat traits evaluated during the previous three years $(2016,2017$, and 2018) and at the time of selection [18]. In total, 60 ewes with defects or a history of defects and 20 with consistently normal udders were selected. These ewes were transported to Massey University's Keeble farm (Palmerston North, New Zealand) in January 2019.

\subsection{Animal Management}

From the time of arrival at Keeble farm, the ewes were managed as a single flock under commercial grazing conditions. For breeding, ewes were progesterone-synchronised by inserting a controlled release intravaginal device (Eazi-Breed CIDR ${ }^{\circledR}$, Zoetis New Zealand) on 13 March 2019 for a period of 12 days. Pregnancy diagnosis was undertaken twice in mid-pregnancy (4 June and 25 July) using trans-abdominal ultrasonography undertaken by a commercial operator to confirm pregnancy and foetus numbers. Single and twin-bearing ewes were retained while non-pregnant and triplet-bearing ewes were culled $(n=21)$.

On 30 July 2019, all ewes were weighed, body condition scored, and moved to a single paddock closer to the milking parlour with a pasture requirement according to commercial conditions for late pregnant ewes (pre-lambing). Forty-eight ewes were retained for lambing and the lambing period occurred between 13 August and 9 September 2019. On milking days (see below), lambs were separated from their dams for six hours between morning and afternoon milkings, during which time each lamb was bottle-fed $300 \mathrm{~g}$ of ewe's milk [37]. If a ewe produced less than $1200 \mathrm{~g} /$ day of milk or abandoned their lamb/s, the lamb/s was/were removed from the ewe and fostered. These ewes, and ewes for whom all their lambs died (18), were excluded from the milking study.

\subsection{Milking and Milk Yield Calculation}

Each ewe was milked six times during lactation at seven-day intervals, beginning 5-8 days after lambing. There were two milking groups: ewes that lambed on SundayTuesday were milked on Mondays while those that lambed on Thursday-Saturday were milked on Fridays. Ewes that lambed on Wednesday (21 August 2019) were milked once on Wednesday and then joined the Friday milking group to balance group sizes. Each milking group contained ewes with a history of both normal udders and udder defects. The milking procedure was as follows. Briefly, milking was achieved by injecting oxytocin (oxytocin-EA (Ethical Agents Ltd., Auckland, New Zealand) (1 IU) diluted with $0.9 \mathrm{~mL}$ of physiological saline into the jugular vein $0.5-1 \mathrm{~min}$ before milking commenced [37]. At each milking (morning (approximately starting at $9 \mathrm{am}$ ) and afternoon (approximately starting at $3 \mathrm{pm})$ ), ewes were machine-milked for approximately two minutes after which any remaining milk in the mammary gland was expressed by hand. In the morning, the time of milking was recorded individually for each ewe. The ewes, without their lambs, were then put back onto pasture until the afternoon milking. In the afternoon, milk from each udder-half was collected into a separate container and the weight of milk (g) collected and time were recorded. To estimate a 'daily' milk yield, the weight of milk collected from the afternoon milking and the inter-milking interval time were used to calculate a 'daily' (24 h) milk yield from each udder-half. The 'daily' whole-udder milk yield was calculated as the sum of milk yield from two udder halves for each ewe [38] 


\subsection{Milk Sampling and Laboratory Analysis}

The milk collected was gently mixed by inverting the collection container and 10 and $50 \mathrm{~mL}$ of milk were removed into separate sampling vials for somatic cell count (SCC) and milk composition analysis, respectively. SCC was assessed $2-4 \mathrm{~h}$ post-collection on the same day (see details below). Milk samples collected for composition analysis were stored in a refrigerator $\left(+4^{\circ} \mathrm{C}\right)$ overnight and analysed the next day.

\subsection{Somatic Cell Count (SCC) Determination}

Somatic cell count analysis of milk from each udder-half was performed using a DeLaval cell counter (DCC) (DeLaval Int. AB, Tumba, Sweden) according to the method of Gonzalo, et al. [25]. Milk was extracted from the sample vial into the DCC cassette, which contained a small amount of fluorescent stain and Triton X-100, and provided cell counts per $\mathrm{ml}$ within approximately $1 \mathrm{~min}$. The DCC captured a digital picture of each somatic cell's nucleus, which was then stained in the cassette with a DNA-specific fluorescent reagent enabling each cell's nuclei to be counted. A small number of samples with clots or blood (signs consistent with clinical mastitis) could not be analysed as the presence of clots meant they were unable to be read by the machine; these were excluded from the analysis.

\subsection{Milk Component Analysis}

Analysis of milk components including fat, protein, lactose, total solids, and non-fat solids (NFS) were determined using a Milkoscan FT1 (Foss Electric, Hillerød, Denmark). The stored milk samples were placed in a water bath $\left(40{ }^{\circ} \mathrm{C}\right)$ before the analysis and carefully inverted to homogenize the fat. The Milkoscan was set to allow triplicate analyses from the single sample and provided these three results along with the mean and standard deviation. Sheep milk calibration was developed using Fourier transform infrared spectroscopy (FTIRS) through a Milkoscan FT1 machine and the details of the Milkoscan calibrations are summarized in Table A1.

\subsection{Udder Scoring}

Udder scoring of the ewes was undertaken using the methods described by Griffiths, et al. [18] each week for the first six weeks of lactation (on the same day as milking). All ewes were udder-scored at these times, regardless of whether they reared a lamb and were milked.

\subsection{Data Management}

For analysis of the data, the 7-category udder scoring system as described by Griffiths, et al. [18], was condensed into three categories: Score 7 was categorised as 'hard', scores 3-6 as 'lump', and scores 1 and 2 as 'normal' [18]. Udders or udder halves categorised as 'hard' or 'lump' were considered defective. During the six examinations in lactation, it was observed that most udder-half defects changed category over time (e.g., hard changed to lump). To account for these changes and potential effects on the trait measured, additional sub-categories were developed (Table 1).

Combined over the six once-weekly milk collections from the 30 ewes, the dataset for udder-half consisted of 352 daily milk yields. Four ewes missed the last milking. When udder-half observations with no milk were excluded, the dataset included 262 values. This was further reduced to 255 values for SCC and 243 values for milk composition analyses. Fewer samples were available for SCC and milk composition due to no expression of milk or an inadequate volume of milk to conduct the appropriate tests. The total number for the analysis of whole-udder milk yield consisted of 176 whole-udder observations (i.e., half of 352 daily yields; however, only 123 individual udder-half observations expressed milk from both udder halves). For the analysis between the overall defect type and wholeudder milk yield, six observations from five udders with bilateral udder defects were excluded $(n=170)$. 


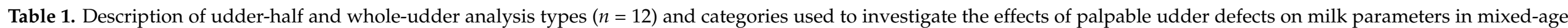
non-dairy breed (Romney) ewes, which were examined six times at weekly intervals, starting at day 7 of lactation.

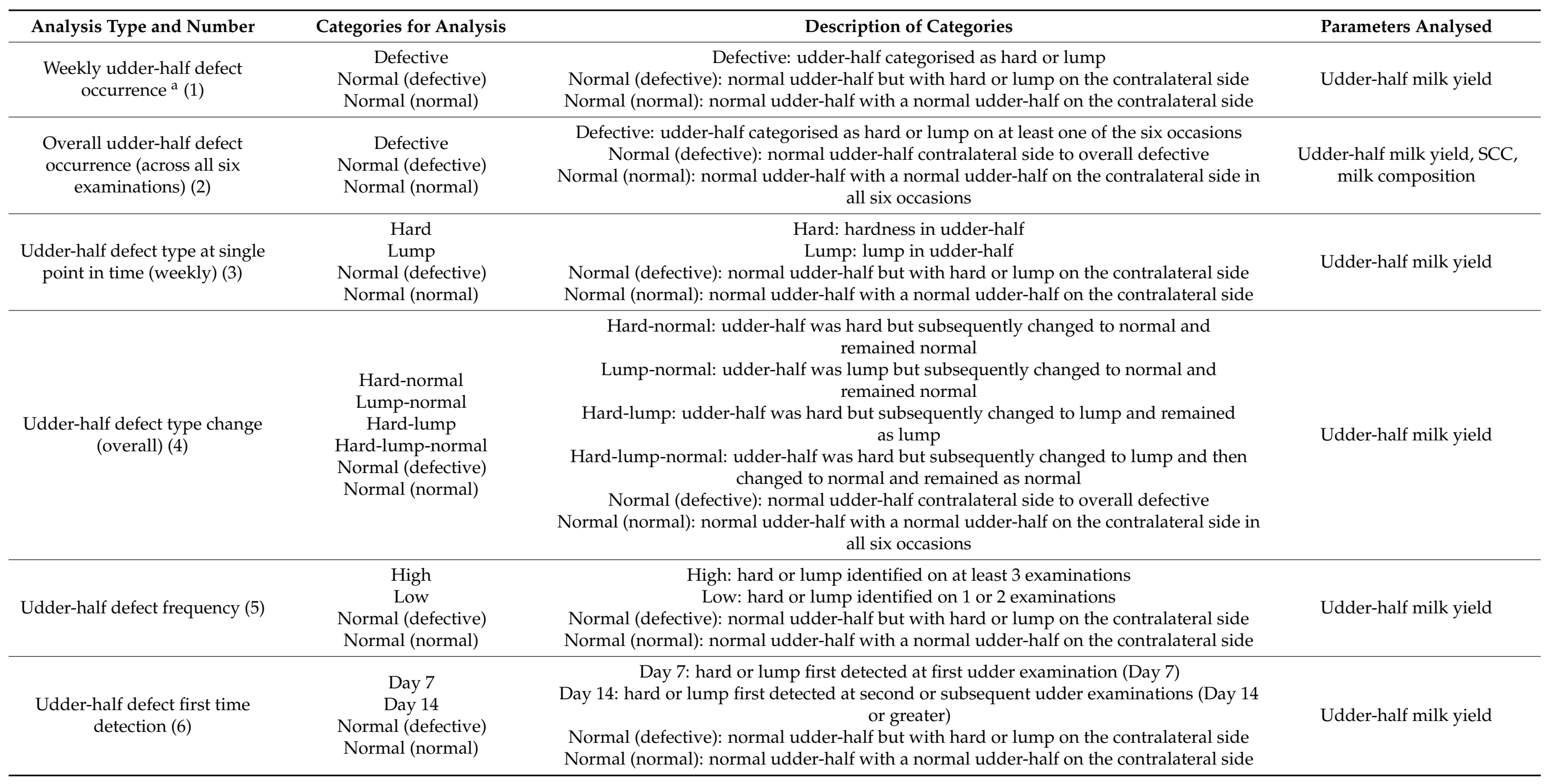


Table 1. Cont.

\begin{tabular}{|c|c|c|c|}
\hline Analysis Type and Number & Categories for Analysis & Description of Categories & Parameters Analysed \\
\hline $\begin{array}{l}\text { Weekly whole-udder defect } \\
\text { occurrence }^{\text {a }}(7)\end{array}$ & $\begin{array}{l}\text { Defective } \\
\text { Normal (both) }\end{array}$ & $\begin{array}{l}\text { Defective: One or both udder halves categorised as hard or lump } \\
\text { Normal (both): both udder halves normal in all six occasions }\end{array}$ & Whole-udder milk yield \\
\hline $\begin{array}{l}\text { Whole-udder defect across all } \\
\text { six examinations (overall) (8) }\end{array}$ & $\begin{array}{l}\text { Defective } \\
\text { Normal (both) }\end{array}$ & $\begin{array}{c}\text { Defective: One or both udder halves categorised as hard or lump on at least one of the } \\
\text { six occasions } \\
\text { Normal (both): both udder halves normal in all six occasions }\end{array}$ & Whole-udder milk yield \\
\hline $\begin{array}{l}\text { Whole-udder defect type at } \\
\text { each examination (weekly) (9) }\end{array}$ & $\begin{array}{l}\text { Hard } \\
\text { Lump } \\
\text { Normal (both) }\end{array}$ & $\begin{array}{l}\text { Hard: One or both udder halves categorised as hard or 'lump' on one udder-half and 'hard' } \\
\text { on the other half } \\
\text { Lump: One or both udder halves categorised as lump } \\
\text { Normal (both): both udder halves normal }\end{array}$ & Whole-udder milk yield \\
\hline $\begin{array}{l}\text { Unilateral udder defect type } \\
\text { change (overall) (10) }\end{array}$ & $\begin{array}{l}\text { Hard-normal } \\
\text { Hard-lump } \\
\text { Hard-lump-normal } \\
\text { Lump-normal } \\
\text { Normal (both) }\end{array}$ & $\begin{array}{l}\text { Hard-normal: one udder-half was hard but subsequently changed to normal and } \\
\text { remained normal } \\
\text { Hard-lump: one udder-half was hard but subsequently changed to lump and remained } \\
\text { as lump } \\
\text { Hard-lump-normal: udder-half was hard but subsequently changed to lump and then } \\
\text { changed to normal and remained as normal } \\
\text { Lump-normal: udder-half was lump but subsequently changed to normal and } \\
\text { remained normal } \\
\text { Normal (both): both udder halves normal in all six occasions }\end{array}$ & Whole-udder milk yield \\
\hline $\begin{array}{l}\text { Whole-udder defect } \\
\text { frequency }{ }^{c}(11)\end{array}$ & $\begin{array}{l}\text { High } \\
\text { Low } \\
\text { Normal (both) }\end{array}$ & $\begin{array}{l}\text { High: hard or lump identified on at least } 3 \text { examinations } \\
\text { Low: hard or lump identified on } 1 \text { or } 2 \text { examinations } \\
\text { Normal (both): both udder halves normal }\end{array}$ & Whole-udder milk yield \\
\hline $\begin{array}{l}\text { Whole-udder defect first time } \\
\text { detection (12) }\end{array}$ & $\begin{array}{c}\text { Day } 7 \\
\text { Day } 14 \\
\text { Normal (both) }\end{array}$ & $\begin{array}{l}\text { Day 7: One or both udder halves categorised as hard or lump first detected at first udder } \\
\text { examination (Day 7) } \\
\begin{array}{c}\text { Day 14: One or both udder halves categorised as hard or lump first detected at second or } \\
\text { subsequent udder examinations (Day } 14 \text { or greater) } \\
\text { Normal (both): both udder halves normal }\end{array}\end{array}$ & Whole-udder milk yield \\
\hline
\end{tabular}

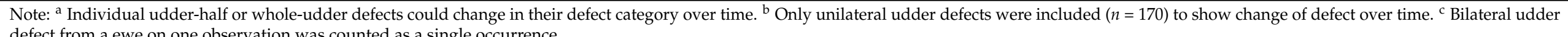




\subsection{Statistical Analysis}

All data were entered to MS-Excel (2016) and analysed using the statistical package R version 3.6.0 [39]. Analyses were undertaken both at the udder-half and whole-udder level.

\subsubsection{Udder-Half Data Analysis}

Udder-half milk yield, milk natural log-SCC, and milk composition (fat, crude protein, lactose, total solids, and SNF) were the dependent variables considered. Independent variables considered included udder-half defect occurrence, number of lambs born, number of lambs reared, udder-half (left/right), pre-lambing body condition score (BCS), prelambing body weight, udder defect history (over the previous three years), age of ewe, and days in milk. SCC was considered as a predictor variable of milk yield and composition only in those udder halves that expressed milk.

The association of udder-half milk yield was also analysed with various udder-half defect parameters (Table 1). The association of some udder-half defect variables (weekly defect occurrence and weekly and overall udder-half defect type) with SCC and milk composition were not undertaken due to the low numbers of defective udder halves from which milk could be expressed and tested for SCC and composition.

\subsubsection{Whole-Udder Data Analysis}

The association between whole-udder milk yield and udder defect parameters is summarized in Table 1. The same independent variables were considered as those for the udder-half analysis except for udder-half (left/right).

\subsection{Multivariate Model Development and Diagnostics}

Multivariate linear mixed models with ewe identification number as a random effect and AR1 correlation structure were used to analyse the impact of udder-half or whole-udder defect occurrence, types, frequency, and first detection time, on milk yield, natural logSCC, and milk composition. For this purpose, "nlme" package in R was used. A stepwise variable selection based on significance level $(p<0.1)$ was implemented. Interaction of days in lactation with udder defects and its quadratic relationship was tested during the models development. The confounding effect of variables was progressively assessed during steps of model development by monitoring for a substantial increase in beta coefficient and/or decrease in standard errors.

Histograms and QQ plots were used assessing the normality of the data. Homoscedasticity and linearity were checked using fitted vs. predicted values plot, and the variance inflation factor (VIF) was used to determine the multicollinearity among independent variables. $R^{2}$ was used to assess the goodness fit for the models. Outlier observations were removed based on Cook's distance and improvement of $R^{2}$. Least squares mean $(\mathrm{LSM} \pm \mathrm{SEM})$ of dependent variables were calculated by adjusting for significant fixedeffect variables.

\section{Results}

\subsection{The Occurrence of Udder-Half Defects (Weekly and Overall)}

From the total of 48 ewes that lambed, 18 ewes were excluded from the milking study in the first week of lactation because they had lost all their lamb/s. Based on udder palpation seven days after lambing, of these 18 ewes, 39\% were categorised as hard in both udder halves, $33 \%$ were categorised as hard in one udder-half, and $28 \%$ were categorised as lump in one udder-half. Of the 30 ewes that were milked, 14 were single bearing and 16 were twin-bearing, with 9 twin-bearing ewes rearing both lambs.

During the udder palpation assessments, it was observed that most ewes' udder-half defect category changed over time. Figure 1 summarises the occurrence of weekly (A) and overall (B) udder-half defects during the six-week period. The maximum number of udder-half defects was recorded on day 21 (week 3, 35\% of 60 udder halves) and the 
minimum on day 42 (week 6, 5\% of 52 udder halves, Figure 1). Across all six examinations, 87 udder halves ( $24.7 \%$ of the 352 udder-half observations) were defective. Note that four ewes (eight udder halves) were not milked on day 42.
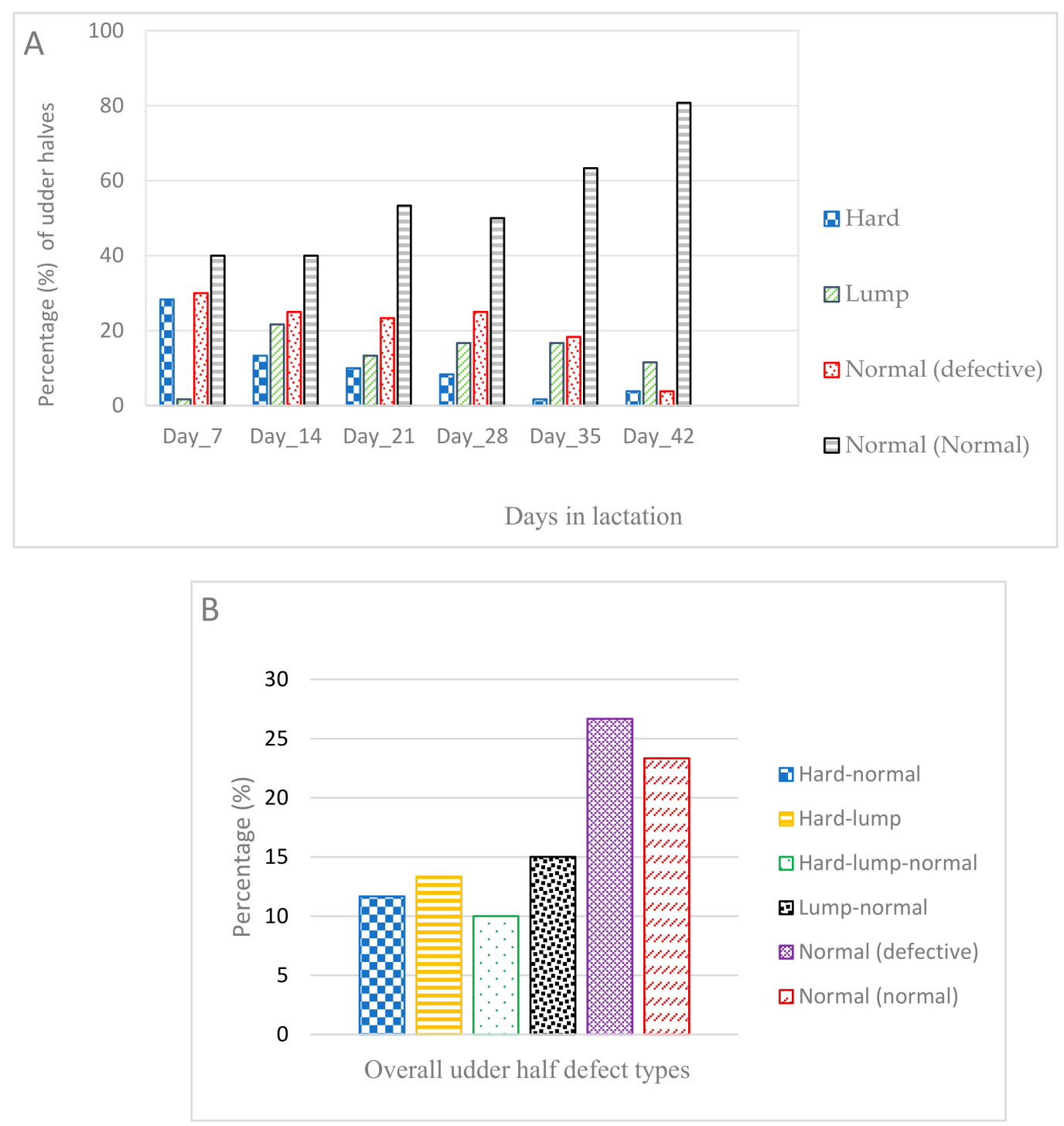

Figure 1. The percentage (\%) of udder-half defect occurrence $(n=60$, i.e., 30 ewes in total), by category in non-dairy ewes whose udder was scored once weekly for the first six-weeks of lactation. (A): percentage of weekly udder-half defect types; (B): Percentage of overall (i.e., classification over the entire six measurements) udder-half defect types; normal udder halves (both in weekly and overall) were sub-categorised into normal (normal) and normal (defective) to account for possible compensatory effects of a normal udder-half when the contralateral udder-half was defective. Normal (normal) refers to a normal udder-half from a ewe in which both udder halves were normal. Normal (defective) refers to a normal udder-half from a ewe where the contra-lateral udder-half was defective. The naming of the overall (progressive) defect categories describes the change in the defect category over time (e.g., hard-lump refers to an udder-half that was first categorised as 'hard' then subsequently was categorised as 'lump' and remained 'lump' until day 42. Note: Four ewes did not have an udder examination on day 42 .

The highest number of udder halves in the category 'hard' occurred at day seven ( $28 \%$ of the 60 udder halves, Figure 1A) but decreased to $3.8 \%$ by day 42 (week six). A total of $35 \%$ of the 60 udder halves were categorised as 'hard' at least once during the six-weeks. In contrast, udder halves in the category 'lump' were lowest at day seven (week one, 1.6\% of the 60 udder halves) but had increased to $16.7 \%$ by day 14 (week two) and remained at similar levels to day 42 (week six). A total of $35 \%$ (of the 60 udder halves) were categorised 
'lump' at least once over the six weeks. Combined over all six weeks, $50 \%$ of 60 udder halves were defective at least once (Figure 1B). Most of the udder-half defects (83.3\% of the 30 defective udder halves) were detected in the first two weeks (14 days) post-lambing. Five udder halves ( $16.7 \%$ of the 30 udder halves) were identified as defective only once, while the rest were observed to be defective on two or more occasions.

During the six weeks, many of the udder-half defects changed in category over time. A third of the 21 udder halves initially categorised as 'hard' changed to normal and the rest changed to 'lump' (Figure 1B). Of those that changed to 'lump', more than half remained as 'lump' while the others changed to normal.

\subsection{Udder-Half Milk Expression}

Based on weekly milking status, 18/60 (30\%) of the udder halves included in the study expressed no milk at least once during the six-week period. At day $7,12 / 60(20 \%$ of the udder halves) expressed no milk and this increased to $16 / 60$ (27\%) on day 35 (i.e., week five). Of these 18 udder halves that expressed no milk, 55.5\% expressed no milk on all six occasions, $16.6 \%$ on five, $22.2 \%$ on four, and $0.5 \%$ on just one occasion.

Over the entire 42-day (six-week) milking period, data were available for 352 udder halves of which 90 had no milk expression. Of these 90 udder halves, $28 \%$ were in the category 'hard', 38\% were 'lump', while $34 \%$ were 'normal'. In contrast, when an individual half udder was categorised based on the entire six-week (42-day) period (category 2 in Table 1), the 30 normal (normal) and normal (defective) udder halves expressed milk at every milking. Of the 30 udder halves that expressed no milk, $23 \%$ were categorised as hard-normal $27 \%$ hard-lump, $20 \%$ hard-lump-normal, and 7\% lump-normal.

\subsection{Relationship between Udder-Half Defect Occurrence and Udder-Half Milk Yield}

Normal (normal) udder halves produced more $(p<0.01)$ milk than defective udder halves based on both weekly and overall udder-half defect analysis (Table 2 and Figure 2). Further, normal (defective) udder halves produced more $(p<0.01)$ milk than normal (normal) udder halves. Overall, defective udder halves (defective at least once during the six-weeks) produced $57.9 \%$ less milk than normal (normal) udder halves. In contrast, normal (defective) udder halves produced 33.5\% more milk than normal (normal) udder halves.

Table 2. The effect of weekly ${ }^{4}$ and overall ${ }^{5}$ udder-half defect occurrence on udder-half milk yield $(n=352)$, somatic cell count (SCC) $(n=255)$, and milk composition ( $n=343)($ LSM + SEM) in non-dairy breed (Romney) ewes examined and milked once weekly during the first six weeks of lactation.

\begin{tabular}{|c|c|c|c|c|c|c|}
\hline \multirow{3}{*}{ Dependent Variables } & \multicolumn{6}{|c|}{ Udder-Half Defect Category } \\
\hline & \multicolumn{2}{|c|}{ Normal (Normal) $^{1}$} & \multicolumn{2}{|c|}{ Defective $^{2}$} & \multicolumn{2}{|c|}{ Normal (Defective) ${ }^{3}$} \\
\hline & & SEM & LSM & SEM & LSM & SEM \\
\hline Udder-half milk yield & \multicolumn{6}{|c|}{ LSM } \\
\hline Weekly defect ${ }^{4}$ (g/d) & $1118^{\mathrm{b}}$ & 54.1 & $320^{a}$ & 83.7 & $1785^{c}$ & 90.4 \\
\hline Overall defect ${ }^{5}(\mathrm{~g} / \mathrm{d})$ & $1204^{b}$ & 76.8 & $507^{\mathrm{a}}$ & 53 & $1811^{c}$ & 73.4 \\
\hline $\operatorname{SCC}(1000)$ & 647 & 86.5 & 680 & 82.6 & 633 & 74.9 \\
\hline \multicolumn{7}{|l|}{ Milk composition } \\
\hline Fat $(\%)$ & 7.57 & 0.23 & 7.92 & 0.25 & 7.26 & 0.22 \\
\hline Crude protein $(\%)$ & 4.95 & 0.04 & 4.83 & 0.04 & 4.89 & 0.04 \\
\hline Lactose $(\%)$ & 7.57 & 0.23 & 7.92 & 0.25 & 7.26 & 0.22 \\
\hline Total solids (\%) & 18.3 & 0.25 & 18.7 & 0.29 & 18.5 & 0.26 \\
\hline SNF (\%) & $11.3^{b}$ & 0.07 & $11.0^{\mathrm{a}}$ & 0.08 & $11.3^{b}$ & 0.07 \\
\hline
\end{tabular}

\footnotetext{
${ }^{1}$ Normal (normal): a normal udder-half where the contralateral udder-half was also normal. ${ }^{2}$ Defective: udder-half categorised as hard or lump either in one or both udder halves. ${ }^{3}$ Normal (defective): a normal udder-half where the contralateral udder-half was defective. ${ }^{4}$ Weekly defect: udder-half defect category at each examination. ${ }^{5}$ Overall defect: udder-half category for all six examinations (identified as defective by being 'hard' or 'lump' at least once during the six examinations). For weekly udder defect, individual udder-half could be identified in a different defect category each week whereas, the overall udder defect reflects a single overall udder-half category over the six-week (42 days) period. log-SCC: Natural log of somatic cell count. LSM: least square means. Different superscripts a,b,c within a row indicates significant differences $(p<0.05)$.
} 


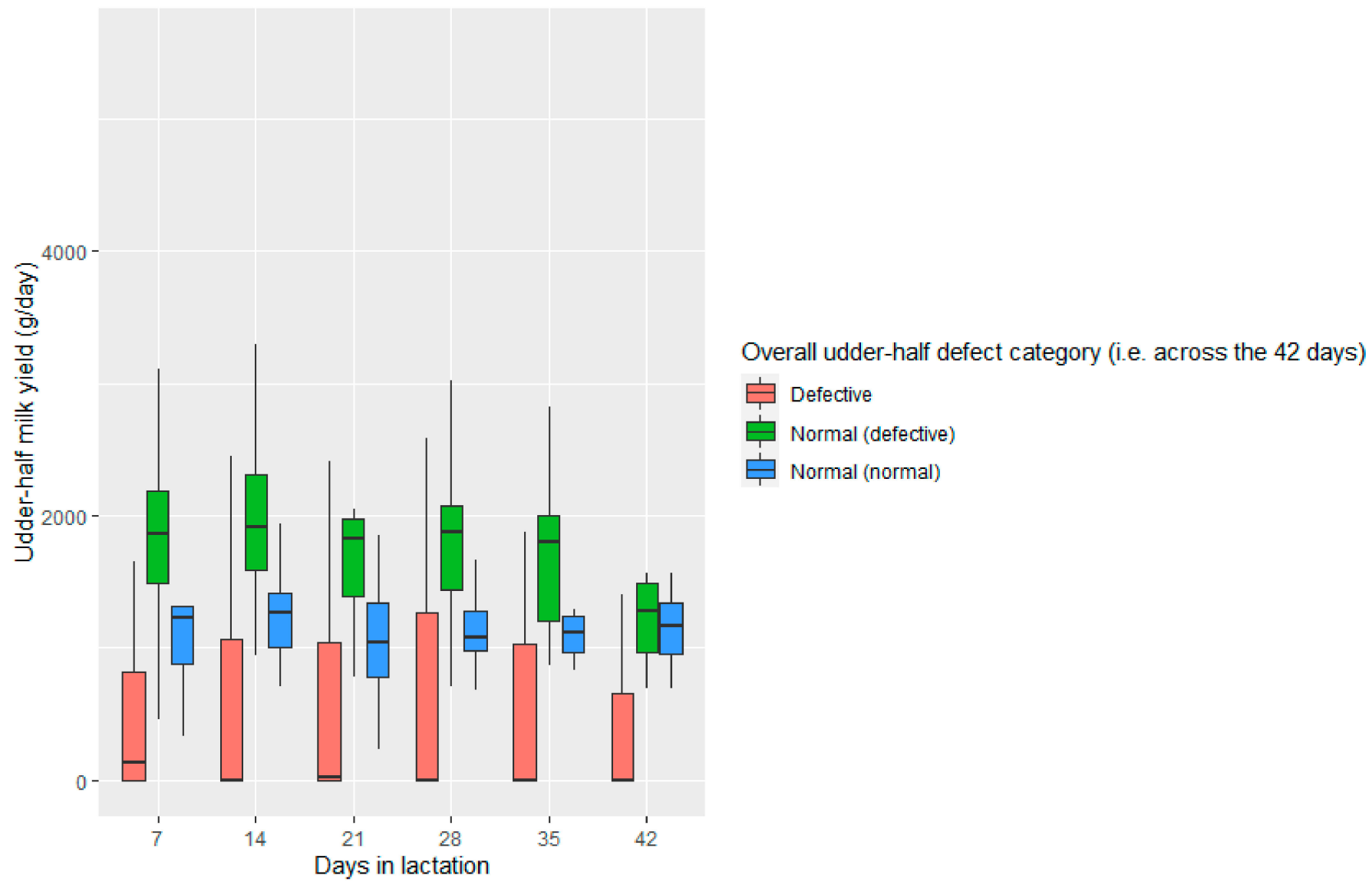

Figure 2. Udder-half milk yield (median and interquartile range) based on overall udder-half defect (i.e., across the 42 days/six-week period) categories in non-dairy Romney ewes $(n=30)$ milked once weekly during the first six weeks of lactation. Udder halves that were categorised as 'hard' or 'lump' on at least one of the six occasions were considered Defective. Normal (defective): was used to describe a normal udder-half where the contralateral udder-half was defective. Normal (normal): was used to describe a normal udder-half where the contralateral udder-half was also normal.

Using the multivariate model, weekly udder-half defect occurrence and the number of lambs each ewe was rearing (rearing rank) were predictors $(p<0.05)$ of udder-half milk yield $\left(R^{2}=0.366\right.$, Table 3$)$, where weekly udder-half defect occurrence explained $36.6 \%$ of the variation in milk yield. The overall udder-half defect explained $39 \%(p<0.05)$ of the milk yield at the half udder level (Table 3).

Further analysis was undertaken to assess the relationship between udder-half defect occurrence and udder-half milk yield, using only those udder halves where milk was actually expressed ( $n=262$, of the total 352 potential udder-half collections over the sixweek period). This analysis identified differences $(p<0.05)$ among weekly and overall udder-half defect categories; however, overall, the differences between the normal and defective categories were less than those identified in the analysis including all 352 udder halves as outlined earlier (Tables 2 and 3 ).

\subsection{Relationship between Udder-Half Defect Occurrence and Somatic Cell Count (SCC)}

The log-SCC was not affected $(p>0.05)$ by overall udder-half defect occurrence (Table 2). Among the independent variables included for udder-half log-SCC analysis, the best fit for the multivariate linear mixed model included birth rank and udder defect history as predictors $\left(p<0.05, R^{2}=0.46\right.$, Table 3$)$, where ewes that gave birth to twins and those with a previous history of udder defects had higher log-SCC than those that gave birth to a single lamb and had no history of udder defects. 
Table 3. Multivariate regression coefficient (Estimate \pm SEM) of udder-half log-SCC $(n=255)$ and milk composition (fat, crude protein, lactose, total solids, and SNF) $(n=243)$ based on overall ${ }^{4}$ udder-half defect from 30 non-dairy breed (Romney) ewes examined and milked weekly during the first six weeks of lactation.

\begin{tabular}{|c|c|c|c|c|c|c|c|c|c|c|c|c|c|c|c|c|}
\hline \multirow{2}{*}{ Parameters } & \multicolumn{2}{|c|}{ Intercept } & \multicolumn{2}{|c|}{ Defective $^{1}$} & \multicolumn{2}{|c|}{$\begin{array}{c}\text { Normal } \\
\text { (Defective) }^{2}\end{array}$} & \multicolumn{2}{|c|}{$\begin{array}{l}\text { Days in } \\
\text { Lactation }\end{array}$} & \multicolumn{2}{|c|}{$\operatorname{SCC}\left(10^{6}\right)$} & \multicolumn{2}{|c|}{$\begin{array}{l}\text { Birth } \\
\text { Rank }\end{array}$} & $\begin{array}{c}\text { Rearing } \\
\text { Rank }\end{array}$ & \multicolumn{2}{|c|}{$\begin{array}{l}\text { Defect } \\
\text { History }\end{array}$} & \multirow{2}{*}{$\mathbf{R}^{2}$} \\
\hline & Est. & SE & Est. & SE & Est. & SE & Est. & SE & Est. & SE & Est. & SE & Est. SE & Est. & SE & \\
\hline \multicolumn{17}{|l|}{ Milk yield } \\
\hline Weekly $^{3}$ & 744.5 & 153.7 & -739.40 & 98.9 & 755.6 & 103.7 & & & & & & & 224.1 & 103.9 & & 0.366 \\
\hline Overall ${ }^{4}$ & 1195.25 & 129.19 & -762.73 & 153.78 & 674.07 & 168.13 & & & & & & & & & & 0.386 \\
\hline \multicolumn{17}{|c|}{ Milk composition } \\
\hline Fat $(\%)$ & 5.97 & 0.32 & & & & & 0.04 & 0.01 & 0.71 & 0.19 & & & & & & 0.67 \\
\hline Protein (\%) & 4.83 & 0.05 & & & & & & & 0.1 & 0.03 & & & & & & 0.49 \\
\hline Lactose (\%) & 5.58 & 0.04 & & & & & & & -0.19 & 0.04 & & & & & & 0.32 \\
\hline Total solids (\%) & 17.05 & 0.34 & & & & & 0.37 & 0.05 & & & & & & & & 0.64 \\
\hline SNF (\%) & 11.74 & 0.16 & -0.30 & 0.18 & 0.07 & 0.2 & -0.01 & 0 & -0.26 & 0.06 & & & & & & 0.3 \\
\hline Log-SCC & 4.84 & 0.35 & & & & & & & & & 0.59 & 0.2 & & 0.46 & 0.19 & 0.46 \\
\hline
\end{tabular}

Normal (normal): a normal udder-half where the contralateral udder-half was also normal. Normal (normal) was used as a reference in all cases. ${ }^{1}$ Defective: an udder-half categorised as hard or lump either in one or both udder halves. ${ }^{2}$ Normal (defective): a normal udder-half but with hard or lump on the contralateral side. ${ }^{3}$ Weekly defect: udder-half defect category at each examination. ${ }^{4}$ Overall defect: udder-half category for all 6 examinations (identified as defective by being 'hard' or 'lump' at least once during the six examinations). For weekly udder defect, individual udder-half could be identified in a different defect category each week whereas, the overall udder defect reflects a single overall udder-half category over the six-week (42 days) period. Log-SCC: Natural log of somatic cell count. All intercepts and estimates were significantly different $(p<0.05)$, except where blank values are shown. Est.: indicates estimate of multivariate coefficient.

\subsection{Relationship between Udder-Half Defect Occurrence and Milk Composition}

There was no association between overall udder-half defect occurrence and milk fat, crude protein, total solids, and lactose $(p>0.05$, Table 2$)$. However, defective udder halves had lower $(p<0.05)$ SNF than the normal (normal) udder halves, whereas no difference was observed between normal (defective) and normal (normal) udder halves $(p>0.05)$.

Days in lactation and SCC were significantly correlated with milk fat, lactose, and SNF $(p<0.05$, Table 3$)$. As days in lactation progressed, fat and total solids increased, but SNF decreased $(p<0.05)$. Fat percentage increased with SCC whereas lactose and SNF were negatively associated $(p<0.05)$.

\subsection{Relationship between Udder-Half Defect Type and Udder-Half Milk Yield}

Udder halves categorised as hard or lump at each examination had lower milk yield $(p<0.05)$ compared with normal (normal) udder halves (Table 4). There were no udder-half milk yield differences $(p>0.05)$ in the overall udder-half defect category (hard-normal) compared with normal (normal) udder halves. However, udder halves that were categorised as hard and then progressed to lump and either remained as lump (hard-lump) or progressed to normal (hard-lump-normal) had a lower milk yield than normal (normal) udder halves (Table 4). Additionally, milk yield in udder halves identified as lump that changed to normal (lump-normal) was lower $(p<0.05)$ than normal (normal) udder halves (Table 4). For the multivariate analysis of udder-half weekly milk yield, there was a significant interaction $(p<0.05)$ between days in lactation and udder halves categorised as hard (Table 4). This was due to an increase in the udder-half milk yield in the later days of lactation for udder halves categorised as hard $(p<0.05)$. This is likely explained by a decreased occurrence of udder halves categorised as hard as the days in lactation advanced, as the category changed to lump or normal (Figure 1). Hard-lump and hard-lump-normal udder-half categories had lower $(p<0.05)$ udder-half milk yield compared with normal (normal) udders (Table 4). 
Table 4. Multivariate analysis coefficient (Estimate \pm SEM) of weekly udder-half milk yield (g/d) based on either weekly 6 or overall ${ }^{7}$ udder-half defect types from 352 individual udder-half observations from 30 non-dairy breed (Romney) ewes examined and milked weekly during the first six weeks of lactation.

\begin{tabular}{|c|c|c|c|c|c|}
\hline \multirow{3}{*}{ Udder-Half Defect Parameters } & \multicolumn{4}{|c|}{ Udder-Half Milk Yield (g/d) } & \multirow{3}{*}{$p$-Value } \\
\hline & \multicolumn{2}{|c|}{ Weekly Defect ${ }^{6}$} & \multicolumn{2}{|c|}{ Overall Defect $^{7}$} & \\
\hline & Estimate & SEM & Estimate & SEM & \\
\hline Intercept & 1255.49 & 151.37 & 1197.73 & 135.05 & $<0.001$ \\
\hline Hard & -924.50 & 245.97 & & & $<0.001$ \\
\hline Lump & -362.50 & 279.55 & & & NS \\
\hline Days in lactation & -71.17 & 32.86 & & & 0.03 \\
\hline Hard $X$ days in lactation & 229.74 & 75.85 & & & $<0.001$ \\
\hline Lump X days in lactation & -2.82 & 67.20 & & & NS \\
\hline Normal (defective) $X$ days in lactation & -152.43 & 60.07 & & & 0.01 \\
\hline Normal(defective) ${ }^{1}$ & 943.35 & 215.62 & 647.77 & 170.15 & $<0.001$ \\
\hline Hard-normal ${ }^{2}$ & & & -231.77 & 216.39 & NS \\
\hline Hard-Lump ${ }^{3}$ & & & -1303.20 & 195.39 & $<0.001$ \\
\hline Hard-lump-normal 4 & & & -1189.52 & 209.03 & $<0.001$ \\
\hline Lump-normal $^{5}$ & & & -356.22 & 192.04 & NS \\
\hline $\mathrm{R}^{2}$ & & 0.28 & & 0.53 & \\
\hline
\end{tabular}

Normal (normal): normal udder-half with a normal udder-half on the contralateral side. Normal (normal) was used as a reference in all cases. ${ }^{1}$ Normal (defective): normal udder-half but with hard or lump on the contralateral side. ${ }^{2}$ Hard-normal: udder-half was hard but subsequently changed to normal and remained normal. ${ }^{3}$ Hard-lump: udder-half was hard but subsequently changed to lump and remained as lump. ${ }^{4}$ Hard-lump-normal: udder-half was hard but subsequently changed to lump and then changed to normal and remained as normal. ${ }^{5}$ Lump-normal: udder-half was lump but subsequently changed to normal and remained normal. ${ }^{6}$ Weekly defect: udder-half defect category at each examination. ${ }^{7}$ Overall defect: udder-half category for all six examinations (identified as defective by being 'hard' or 'lump' at least once during the six examinations). For weekly udder defect, individual udder-half could be identified in a different defect category each week whereas, the overall udder defect reflects a single overall udder-half category over the six-week (42 days) period. All intercepts and estimates were significantly different $(p<0.05)$, except where blank values are shown.

\subsection{Relationship between Udder-Half Defect Frequency and Udder-Half Milk Yield}

Udder halves with a high udder defect frequency (defects identified on three to six occasions) produced less milk ( $p<0.05,88.5 \%$ less) than normal (normal) udder halves (Table 5). However, no differences $(p>0.05)$ were observed between udder halves with low defect frequency (one to two occasions) and normal (normal) udders. The best fit multivariate model for udder-half milk yield consisted only of udder-half defect frequency, which explained $46 \%(p<0.005)$ of the variation (Table 5$)$.

Table 5. Multivariate analysis (estimate \pm SE) of weekly udder-half milk yield (g/d) based on udder-half defect detection frequency and first defect detection time from 352 udder-half observations from 30 non-dairy breed (Romney) ewes examined and milked weekly during the first six weeks of lactation.

\begin{tabular}{|c|c|c|c|}
\hline \multirow{2}{*}{ Parameters } & \multicolumn{2}{|c|}{ Udder-Half Milk Yield (g/d) } & \multirow{2}{*}{$\mathbf{R}^{2}$} \\
\hline & Estimate & SE & \\
\hline \multicolumn{3}{|c|}{ Effect of udder-half defect frequency } & \multirow{5}{*}{0.46} \\
\hline Intercept $(\mathrm{g} / \mathrm{d})$ & 1246.19 & 116.69 & \\
\hline High $(3-6)^{1}$ & -1081.73 & 149.02 & \\
\hline Low $(1-2)^{2}$ & $-266.16^{\mathrm{NS}}$ & 156.67 & \\
\hline Normal (defective) ${ }^{3}$ & 510.15 & 152.88 & \\
\hline \multicolumn{3}{|c|}{ Effect of udder-half defect first detection time } & \multirow{5}{*}{0.29} \\
\hline Intercept & 1279.23 & 115.67 & \\
\hline Day $7^{4}$ & -841.39 & 143.35 & \\
\hline Day 14 and above ${ }^{5}$ & -585.27 & 161.63 & \\
\hline Normal (defective) ${ }^{3}$ & 526.49 & 163.68 & \\
\hline
\end{tabular}

Normal (normal): normal udder-half with a normal udder-half on the contralateral side. Normal (normal) was used as a reference in all cases. ${ }^{1}$ High: hard or lump identified on at least three examinations. ${ }^{2}$ Low: hard or lump identified on one or two examinations. ${ }^{3}$ Normal (defective): normal udder-half but with hard or lump on the contralateral side. ${ }^{4}$ Day 7: hard or lump first detected at first udder examination at end of week one (Day seven). ${ }^{5}$ Day 14: hard or lump first detected at second or subsequent udder examinations (Day 14 or greater). LSM: least square means. All estimates were significant $(p<0.05)$, except with NS. 


\subsection{Relationship between First Defect Detection Time and Udder-Half Milk Yield}

Udder halves detected with a defect for the first time on day seven (end of week one) had lower $(p<0.05)$ milk yield than normal (normal) udder halves, but there was no difference $(p>0.05)$ in milk yield between udder halves detected with a defect on day 14 (end of week two) or later and normal (normal) udder halves (Table 5). The best fit multivariate model for udder-half milk yield consisted only udder-half defect first detection time, which explained $29 \%$ of the variation (Table 5).

\subsection{The Occurrence of Whole-Udder Defects}

Figure 3 shows the occurrence of weekly whole-udder defects during the first six weeks of lactation. A total of 23 whole-udders from the 30 ewes $(77 \%)$ were defective at least once during the six once-weekly examinations. Most whole-udder defects were unilateral (i.e., defect in one udder-half only), except in five ewes, in which a bilateral defect was observed on one or two occasions.

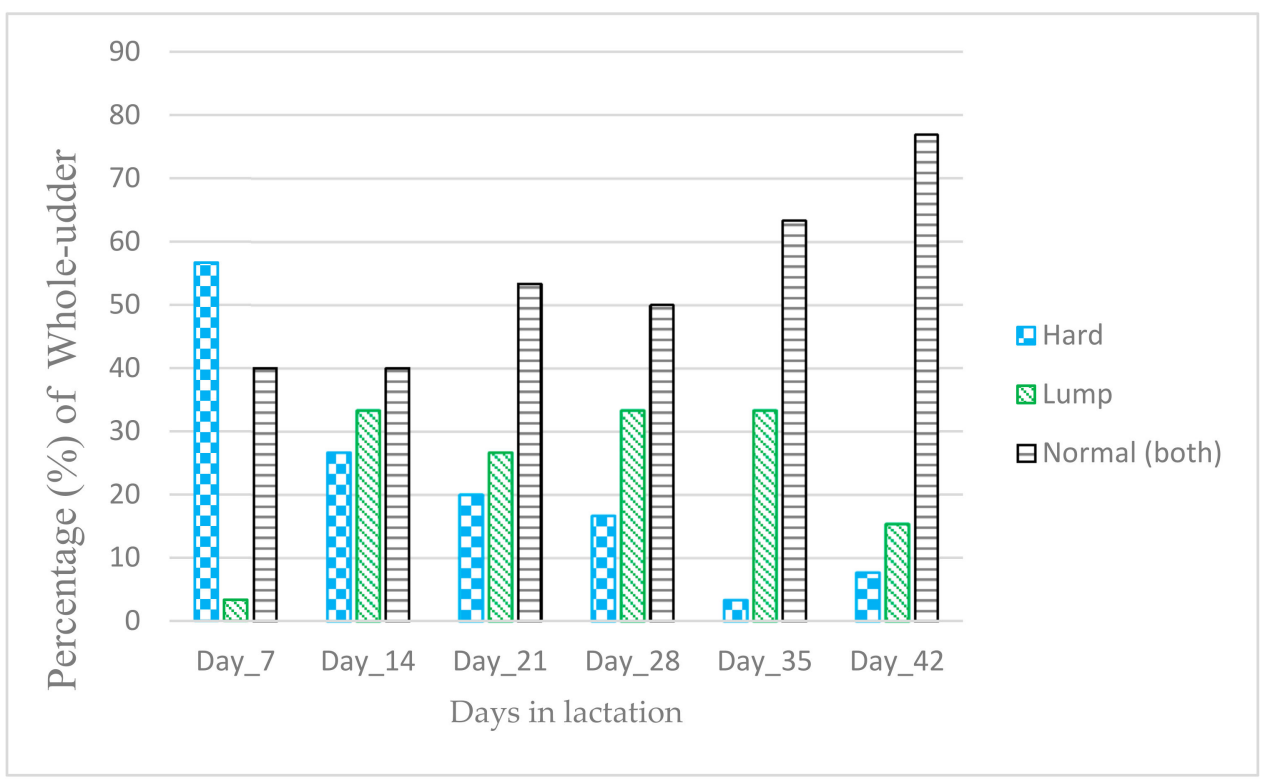

Figure 3. The percentage (\%) of weekly whole-udder defect types in 30 non-dairy Romney breed ewes udder scored once weekly during the first six weeks of lactation. The naming of the overall (progressive) whole-udder defect types describes the change in defect category over time: Hard: was used to describe occurrence of 'hard' in one udder-half and 'normal' or 'lump' on the other udder halves; Lump: was used to describe occurrence of 'lump' either in one or both udder halves; Normal-both: both udder halves normal; For weekly whole-udder defect, individual udder-half could be identified in a different defect category each week over the six-week (42 days) period. Note four ewes were not udder scored on day 42 (end of week six).

\subsection{Relationship between Whole-Udder Defect Occurrence and Whole-Udder Milk Yield}

There was no association $(p>0.05)$ between weekly or overall udder-half defect occurrence and whole-udder milk yield. The best fit regression model had rearing rank as a predictor with an intercept of $1532.8 \mathrm{~g} / \mathrm{d}( \pm$ SE 255.70) and a rearing rank coefficient of 410.79 ( \pm SE 185.8). As such, twin-rearing ewes displayed higher $(p<0.05)$ whole-udder milk yields compared to single-rearing ewes. Similarly, there was no difference $(p>0.05)$ in whole-udder milk yield between normal (both) and defective whole-udder categories from those udders $(n=123)$ which expressed milk from both udder halves.

\subsection{Relationship between Defect Type and Whole-Udder Milk Yield}

Weekly whole-udder defect type had no effect $(p>0.05)$ on whole-udder milk yield (Table 6); however, the whole-udders categorised as hard-lump produced less $(p<0.05$, 
$20.7 \%$ less) milk compared with normal (both) whole-udders. The overall whole-udder defect and rearing rank were predictors $(p<0.05)$ for the best fit multivariate model $\left(\mathrm{R}^{2}=0.29\right)$ for whole-udder milk yield (Table 6).

Table 6. Multivariate analysis coefficient (estimate + SEM) of weekly whole-udder milk yield (g/d) based on either weekly ${ }^{1}$ or overall ${ }^{2}$ udder-half defect types from 170 individual whole-udder observations from 30 non-dairy breed (Romney) ewes examined and milked weekly during the first six weeks of lactation.

\begin{tabular}{|c|c|c|c|c|}
\hline \multirow{2}{*}{ Dependent Variables } & \multirow{2}{*}{ Category } & \multicolumn{2}{|c|}{ Milk Yield (g/d) } & \multirow{2}{*}{$\mathbf{R}^{2}$} \\
\hline & & Estimate & SEM & \\
\hline \multicolumn{5}{|c|}{ Weekly whole-udder defect type ${ }^{1}$} \\
\hline Intercept & & 1532.8 & 255.7 & 0.26 \\
\hline \multirow[t]{2}{*}{ Rearing rank } & & 410.8 & 185.8 & \\
\hline & Overall whole-ud & type $^{2}$ & & \\
\hline Intercept & & 1761.2 & 317.1 & \\
\hline \multirow{4}{*}{$\begin{array}{l}\text { Overall whole-udder } \\
\text { defect type }\end{array}$} & Hard-normal $^{3}$ & $-232.1 \mathrm{NS}$ & 238.3 & 0.29 \\
\hline & Hard-lump ${ }^{4}$ & -562.4 & 239.0 & \\
\hline & Hard-lump-normal 5 & $213.2^{N S}$ & 236.7 & \\
\hline & Lump-normal ${ }^{6}$ & $-270.4^{\mathrm{NS}}$ & 240.5 & \\
\hline Rearing rank & & 357.0 & 176.6 & \\
\hline
\end{tabular}

${ }^{1}$ Weekly whole-udder defect type: udder defect type at each examination. ${ }^{2}$ Overall whole-udder defect type: unilateral defect type change across all six examinations. ${ }^{3}$ Hard-normal: udder-half was hard but subsequently changed to normal and remained normal. ${ }^{4}$ Hard-lump: udder-half was hard but subsequently changed to lump and remained as lump. ${ }^{5}$ Hard-lump-normal: udder-half was hard but subsequently changed to lump and then changed to normal and remained as normal. ${ }^{6}$ Lump-normal: udder-half was lump but subsequently changed to normal and remained normal. Normal: both udder halves normal (Reference). Normal (both) was used as a reference in whole-udder analysis. Note: Four ewes were not milked on day 42 (end of week six). NS: Not significant $(p<0.05)$.

\subsection{Relationship between Whole-Udder Milk Yield and Whole-Udder Defect Frequency}

There were no differences $(p>0.05)$ in whole-udder milk yield between whole-udder defect frequency categories (high: defect identified on three to six occasions, or low: one to two occasions) compared to normal (both) udders (data not shown).

\subsection{Relationship between Whole-Udder Milk Yield and Whole-Udder Defect First Defect Detection Time}

Whole-udder milk yield was not different $(p>0.05)$ between udders where both halves were normal compared with udders where one or both udder halves were found to be defective at either day 7 or day 14 and later (data not shown).

\section{Discussion}

This study was undertaken to assess the effect of palpable udder defects on milk yield and milk composition in non-dairy breed (Romney) ewes. Udder defects and milk parameters were analysed both at the udder-half and whole-udder level. Udder defects are relatively common in ewes in New Zealand, with previous studies undertaken between weaning and mating reporting a $2.3-7 \%$ prevalence $[3,19,21]$. Recently, Griffiths, et al. [18] studied palpable udder defects in Romney ewes at pre-mating, pre-lambing, docking (approximately four weeks post-lambing), and weaning and reported an occurrence of udder defects of $6.0,5.0,7.5$, and $7.4 \%$, respectively. The occurrence of palpable udder defects in early lactation is not well understood, but it has been suggested to be higher than at other times [19]. Internationally, studies on udder defects in non-dairy ewes have shown comparable occurrence rates to those reported in New Zealand and have impacted mammary health and lamb survival and growth [12-16]. Despite this, there appears to be no available reports on the effects of palpable udder defects on milk yield and milk composition in ewes.

The present study investigated udder defects in a unique population of ewes that had a history of either known udder defects or no defects in the previous three years. From the total 48 ewes that lambed in the present study, 41 ewes ( 23 of 30 milked ewes and all 18 
of the non-milked ewes) had an udder defect in one udder-half on at least one occasion, during their six once-weekly examinations. Thirty eight percent of the ewes that lambed in this study lost all their lambs and a further $12.5 \%$ lost one of their twins. These loss rates are higher than the averages reported in single or twin lambs in New Zealand $[18,40,41]$. In contrast, in the present study, for ewes where both udder halves were categorised as normal throughout the study, all lambs survived. This finding agrees with the potential undesirable impact of udder defects on lamb survival reported previously $[1,15,18]$ and emphasises the importance of udder health and inspection of udders. Ewes that lost all their lambs in the present study either did not express, or only produced very small amounts of, milk from one or both udder halves. Additionally, more than half of the 30 ewes enrolled in the milking study did not express milk from one of the udder halves at least once during the six milkings. Total failure to express milk was seen mainly in udder halves categorised as hard at the time of milking or previously. Similarly, a condition described as hard udder has been reported to interfere with colostrum consumption or cause complete absence of milk, resulting in higher loss rates of lambs and increased culling of ewes [20,23].

Diffuse hardness of the mammary gland ('hard') and lumps of various size and consistency ('lump') were the only categories of palpable udder defects presented in this study. Repeated weekly udder examinations over the six-week period revealed that the palpable udder defects changed over time from either defective to normal or from one defective category to another. Overall, it was observed that the occurrence of udder defects decreased as lactation advanced, particularly in relation to 'hard'. The higher occurrence of udder defects observed in the early lactation period could be associated with higher milk production during this time, which may lead to a reduction in immunological competence [42] or a change in the severity of infection [43]. A change from hard to normal palpation scores in the weeks following parturition has been previously reported by others $[19,20,23]$. However, in some cases, this change took several weeks. This agrees with Grant, et al. [15], who reported that some palpable udder defects persisted during lactation and that these may increase the risk of reoccurrence in the following lactation. This may explain the high rates of udder defects reported in this study, as many of these ewes had a history of udder defects in the previous year/s, with ewes selected specifically because they had a history of palpable udder defects. It might also partially explain the occurrence of a higher percentage of palpable udder defects during lactation than in pregnancy $[15,18]$.

In this study, which included ewes with a history of udder defects, there was a high occurrence of udder halves categorised as hard at day 7, but which subsequently changed to lump or normal within 2-6 weeks post-lambing. Traditionally, farmers in New Zealand examine the udders of ewes at weaning and/or pre-mating. A recent longitudinal cross-sectional study by Griffiths, et al. [18] assessed ewes' udders during late pregnancy, mid-lactation, weaning, and pre-mating. However, New Zealand-based studies examining udders in early lactation are limited and these included only a small number of ewes and the only focus was a condition described as hard udder [20,23]. Further investigation of udder defects in early lactation could provide further valuable information to explain the pathological process and bacterial flora associated with this defect and the process of progression over time.

Udder halves with a defect observed at least once in six-weekly examinations produced $57.9 \%$ (range 27.5 to $99.8 \%$ ) less milk than udder halves categorised as normal over the entire period. Further, normal udder halves yielded at least twice as much milk compared with udder halves initially categorised as hard but which changed to lump or to lump and then normal over the six-week period (i.e., hard-lump or hard-lump-normal). The loss of milk yield in these udder halves was much higher than those categorised as either hard or lump alone. Additionally, udder halves with a higher udder-half defect detection frequency (i.e., defect detected on more than three out of six examinations) produced up to $88.5 \%$ less milk than the normal udders, while udder halves detected with a defect in the first week of lactation produced $65.1 \%$ less milk than a normal udder-half. Based on these 
results, it is apparent that sequential occurrence of both hard and lump (e.g., hard-lump) early in the lactation period, and/or persistency of defects over time, resulted in a greater loss of udder-half milk yield. There are no other studies available that report the effect of palpable udder defects on milk yield. However, the occurrence of sub-clinical mastitis in early lactation has been associated with a significant loss of milk yield in ewes $[11,30,44]$.

In the present study, normal udder halves contralateral to a defective udder half (i.e., described as normal (defective)) produced higher milk yield than normal udder halves with a contralateral normal (i.e., described as normal (normal)). This is most likely due to a compensatory increase in milk production by the normal udder halves in response to the decrease by the contralateral defective. As a result, whole-udder milk yield presented no difference between defective and normal udders, except only in the case of whole-udders detected with hard that changed to lump and persisted (hard-lump). Marti De Olives, et al. [11] quantified a 15-17\% loss of whole-udder milk yield in udders detected with unilateral sub-clinical mastitis compared to normal udders. Hence, while there is a level of compensation by the normal udder-half, it may not be enough to compensate fully for reduced production in the impaired udder, which would impact on total lactation yield and lamb growth and survival as was demonstrated in a large field study [18]. In ewes with an udder-half defect or no milk expression from one udder-half, twin lambs would likely be most affected due to competition to access adequate milk yield compared to singletons. Even in a fully functional udder, the milk production of twin-rearing ewes is not twice that of a ewe rearing a singleton [45]. This situation would likely exacerbate the effect of udder defects on twin lamb survival and weight gain, even if there was no difference in whole-udder milk yield between ewes with normal or defective whole-udders.

Udder halves that expressed very little or no milk during a milking event were excluded from somatic cell count (SCC) and milk composition analysis due to insufficient samples for laboratory testing. Hence, inference of SCC and milk composition parameters should be made in consideration of these limitations. The SCC cut-off point to indicate mammary infection in ewes has been reported to range from 300,000 to 1,000,000 [46], indicating a lack of consensus [47]. The present study found milk SCC was not different between defective and normal categories, as some individual udder halves in both categories were observed to have high SCC (i.e., more than one million). High SCC in the normal udders in the present study could be due to subclinical mastitis, while udder halves with lump (assumed to be abscesses) may change in bacterial phenotypic diversity in the mammary gland [26,48], which may result in variation in SCC.

In the current study, only milk solid non-fat (SNF) had any association with udderhalf defects while there were no associations with crude protein, lactose, and total solids. There appears to be no available literature on the effects of palpable udder defects on milk composition in ewes. In a review, Martí-De Olives, et al. [27] reported that the concentration of lactose decreases and whey protein increases with subclinical mastitis while other milk components have been inconsistently influenced (decrease, increase, or no difference) by subclinical mastitis in ewes. Changes in fat and protein (casein) percentages depend on the extent of milk yield loss, due to the dilution or concentration effect. In this study, defective udder halves produced less milk than normal udder halves and the resulting concentration effect on milk composition may explain the lack of variation between defective and normal udder halves [7]. In addition, the total crude protein depends on the casein:protein ratio, which usually decreases as a result of infection $[11,49,50]$. However, whey proteins increase during mammary inflammation or damage to the blood milk-barrier, which is likely to leak from blood to milk [11,49]. Moreover, variation in milk composition due to mastitis depends on the type of infectious agents [7,51]. Generally, previous studies have summarized that quantitative milk production is a better indicator of early lamb growth than milk components; however, milk composition may explain a reasonable proportion [52,53]. 


\section{Conclusions}

In conclusion, the results of this study showed a high occurrence of palpable udder defects in early lactation in non-dairy Romney ewes with a previous history of udder defects. Further, palpable udder defects were associated with both udder-half and wholeudder changes in milk yield, in which the degree of milk loss depended on the type and persistence of the udder defects. Therefore, these findings indicate the importance of udder health in non-dairy ewes and the potential effect on their offspring. However, milk SCC and composition parameters, except SNF, presented no association with palpable udder defects. A high proportion of udder halves were hard seven days after lambing and expressed little to no milk but then changed to lump or normal over the following five weeks. The cause and pathogenesis of this defect is worthy of further consideration.

Author Contributions: Conceptualization, M.M.Z., A.L.R., K.J.F., P.R.K. and S.J.P.; data collection, M.M.Z., A.L.R., K.J.F. and S.W.P.; data analysis, M.M.Z.; data curation, M.M.Z., P.R.K. and K.J.F.; supervision, A.L.R., P.R.K., S.J.P. and D.A.; writing-review and editing, A.L.R., P.R.K., S.J.P., D.A., K.J.F. and S.W.P. All authors have read and agreed to the published version of the manuscript.

Funding: This project is funded by Beef and Lamb New Zealand.

Institutional Review Board Statement: All procedures involving the use of live animals were undertaken in accordance with animal welfare standards and approved by the Massey University Animal Ethics Committee (Application number: MUAEC 15/105).

Data Availability Statement: The data utilised by this study are available on request from the corresponding author.

Acknowledgments: We want to thank Michelle Tamehana, Geoff Purchas, Dean Burnham, and Catriona Jenkinson for their technical support.

Conflicts of Interest: The authors declare no conflict of interest.

\section{Appendix A}

Table A1. Milkoscan FT 1 machine sheep milk calibrations for fat, crude protein, lactose, and total solids.

\begin{tabular}{cccccc}
\hline Component & Intercept & Coefficients & $\begin{array}{c}\text { R- } \\
\text { Squared }\end{array}$ & $\begin{array}{c}\text { Absolute } \\
\text { Accuracy }\end{array}$ & $\begin{array}{c}\text { Relative } \\
\text { Accuracy (\%) }\end{array}$ \\
\hline Fat $(N=51)$ & 0.901 & 0.902 & 0.965 & 0.298 & 3.87 \\
Crude protein $(N=54)$ & -0.61 & 1.11 & 0.977 & 0.067 & 1.134 \\
Lactose $(N=51)$ & 0.840 & 0.765 & 0.796 & 0.10 & 2.18 \\
Total solids $(N=51)$ & 1.878 & 0.909 & 0.986 & 0.206 & 1.113 \\
SNF $(N=51)$ & -1.78 & 1.14 & 0.816 & 0.148 & 1.37 \\
\hline
\end{tabular}

Note: The absolute accuracy expresses Standard Error of Prediction whereas the relative accuracy states Standard Error relative to the mean of the reference values.

\section{References}

1. Hayman, R.; Turner, H.; Turton, E. Observations on survival and growth to weaning of lambs from ewes with defective udders. Aust. J. Agric. Res. 1955, 6, 446-455. [CrossRef]

2. Saratsis, P.; Leontides, L.; Tzora, A.; Alexopoulos, C.; Fthenakis, G.C. Incidence risk and aetiology of mammary abnormalities in dry ewes in 10 flocks in Southern Greece. Prev. Vet. Med. 1998, 37, 173-183. [CrossRef]

3. Quinlivan, T. Survey observations on ovine mastitis in new zealand stud romney flocks: 1. The Incidence of Ovine Mastitis. N. Z. Vet. J. 1968, 16, 149-153. [CrossRef] [PubMed]

4. Fthenakis, G.C.; Jones, J.E.T. Incidence and aetiology of clinical ovine mastitis in flocks in Central Macedonia, Greece. J. Hell. Vet. Medical Soc. 1990, 41, 133-141.

5. Madel, A.J. Observations on the mammary glands of culled ewes at the time of slaughter. Vet. Rec. 1981, 109, 362-363. [CrossRef] [PubMed]

6. Mavrogianni, V.S.; Fthenakis, G.C.; Brooks, H.; Papaioannou, N.; Cripps, P.J.; Taitzoglou, I.; Brellou, G.; Saratsis, P. The effects of inoculation of Mannheimia haemolytica into the teat of lactating ewes. Vet. Res. 2005, 36, 13-25. [CrossRef] 
7. Burriel, A.R. Dynamics of intramammary infection in the sheep caused by coagulase-negative staphylococci and its influence on udder tissue and milk composition. Vet. Res. 1997, 140, 419-423. [CrossRef]

8. Harmon, R.J. Physiology of Mastitis and Factors Affecting Somatic Cell Counts1. J. Dairy Sci. 1994, 77, 2103-2112. [CrossRef]

9. Gelasakis, A.I.; Mavrogianni, V.S.; Petridis, I.G.; Vasileiou, N.G.; Fthenakis, G.C. Mastitis in sheep-The last 10 years and the future of research. Vet. Microbiol. 2015, 181, 136-146. [CrossRef]

10. Gonzalo, C.; Ariznabarreta, A.; Carriedo, J.A.; San Primitivo, F. Mammary pathogens and their relationship to somatic cell count and milk yield losses in dairy ewes. J. Dairy Sci. 2002, 85, 1460-1467. [CrossRef]

11. Marti De Olives, A.; Diaz, J.R.; Molina, M.P.; Peris, C. Quantification of milk yield and composition changes as affected by subclinical mastitis during the current lactation in sheep. J. Dairy Sci. 2013, 96, 7698-7708. [CrossRef]

12. Arsenault, J.; Dubreuil, P.; Higgins, R.; Belanger, D. Risk factors and impacts of clinical and subclinical mastitis in commercial meat-producing sheep flocks in Quebec, Canada. Prev. Vet. Med. 2008, 87, 373-393. [CrossRef] [PubMed]

13. Barber, S. Causes of clinical and sub-clinical mastitis in Australian sheep flocks. In Proceedings of the Australian Veterinary Association (AVA) Annual Conferences-Pan Pacific (NZVA and AVA) Veterinary Conference, Combined Proceedings, Brisbane, Australia, 15 May 2015; pp. 115-122.

14. Cooper, S.; Huntley, S.J.; Crump, R.; Lovatt, F.; Green, L.E. A cross-sectional study of 329 farms in England to identify risk factors for ovine clinical mastitis. Prev. Vet. Med. 2016, 125, 89-98. [CrossRef] [PubMed]

15. Grant, C.; Smith, E.M.; Green, L.E. A longitudinal study of factors associated with acute and chronic mastitis and their impact on lamb growth rate in 10 suckler sheep flocks in Great Britain. Prev. Vet. Med. 2016, 127, 27-36. [CrossRef] [PubMed]

16. Onnasch, H.; Healy, A.; Brophy, P.; Kinsella, A.; Doherty, M. 116. A study of mastitis in Irish sheep. Res. Vet. Sci. 2002, 72, 42. [CrossRef]

17. Clark, R.G. Ovine Mammary Diseases. A Review. In Proceedings of the Society of Sheep and Beef Cattle Veterinarians of the New Zealand Veterinary Association, Christchurch, New Zealand, 11-12 July 1980.

18. Griffiths, K.J.; Ridler, A.L.; Compton, C.; Corner-Thomas, R.A.; Kenyon, P.R. Investigating associations between lamb survival to weaning and dam udder and teat scores. N. Z. Vet. J. 2019, 67, 163-171. [CrossRef]

19. Peterson, S.W.; Nieper, B.; Collett, M.G.; Grinberg, A. BRIEF COMMUNICATION: An investigation of mastitis in a hill-country sheep flock. In Proceedings of the New Zealand Society of Animal Production, Rotorua, New Zealand, 6 June 2017; pp. 114-116.

20. Skyrme, H.P. Hard udders in ewes. N. Z. Vet. J. 1970, 18, 96. [CrossRef]

21. Ridler, A.L.; Rout-Brown, G.; Flay, K.J.; Velathanthiri, N.; Grinberg, A. Defects and bacterial pathogens in udders of non-dairy breed ewes from New Zealand. N. Z. J. Agric. Res. 2021, 1-9. [CrossRef]

22. Fragkou, I.A.; Boscos, C.M.; Fthenakis, G.C. Diagnosis of clinical or subclinical mastitis in ewes. Small Rumin. Res. 2014, 118, 86-92. [CrossRef]

23. Bruce, R.; Collett, M.; Alley, M. Hard udders in ewes in New Zealand. In Proceedings of the International Sheep Veterinary Congress, Rotorua, New Zealand, 18-22 February 2013.

24. Mørk, T.; Waage, S.; Tollersrud, T.; Kvitle, B.; Sviland, S. Clinical mastitis in ewes; bacteriology, epidemiology and clinical features. Acta Vet. Scand. 2007, 49, 23-28. [CrossRef]

25. Gonzalo, C.; Tardáguila, J.A.; De La Fuente, L.F.; San Primitivo, F. Effects of selective and complete dry therapy on prevalence of intramammary infection and on milk yield in the subsequent lactation in dairy ewes. J. Dairy Res. 2004, 71, 33-38. [CrossRef] [PubMed]

26. Smith, E.M.; Willis, Z.N.; Blakeley, M.; Lovatt, F.; Purdy, K.J.; Green, L.E. Bacterial species and their associations with acute and chronic mastitis in suckler ewes. J. Dairy Sci. 2015, 98, 7025-7033. [CrossRef] [PubMed]

27. Martí-De Olives, A.; Peris, C.; Molina, M.P. Effect of subclinical mastitis on the yield and cheese-making properties of ewe's milk. Small Rumin. Res. 2020, 184. [CrossRef]

28. Leitner, G.; Chaffer, M.; Caraso, Y.; Ezra, E.; Kababea, D.; Winkler, M.; Glickman, A.; Saran, A. Udder infection and milk somatic cell count, NAGase activity and milk composition-fat, protein and lactose-in Israeli-Assaf and Awassi sheep. Small Rumin. Res. 2003, 49, 157-164. [CrossRef]

29. Huntley, S.J.; Cooper, S.; Bradley, A.J.; Green, L.E. A cohort study of the associations between udder conformation, milk somatic cell count, and lamb weight in suckler ewes. J. Dairy Sci. 2012, 95, 5001-5010. [CrossRef] [PubMed]

30. Leitner, G.; Chaffer, M.; Shamay, A.; Shapiro, F.; Merin, U.; Ezra, E.; Saran, A.; Silanikove, N. Changes in Milk Composition as Affected by Subclinical Mastitis in Sheep. J. Dairy Sci. 2004, 87, 46-52. [CrossRef]

31. Pulina, G.; Nudda, A.; Macciotta, N.P.P.; Battacone, G.; Giacomo Rassu, S.P.; Cannas, A. Non-nutritional factors affecting lactation persistency in dairy ewes: A review. Ital. J. Anim. Sci. 2007, 6, 115-141. [CrossRef]

32. Leitner, G.; Merin, U.; Krifucks, O.; Blum, S.; Rivas, A.; Silanikove, N. Effects of intra-mammary bacterial infection with coagulase negative staphylococci and stage of lactation on shedding of epithelial cells and infiltration of leukocytes into milk: Comparison among cows, goats and sheep. Vet. Immunol. Immunopathol. 2012, 147, 202-210. [CrossRef]

33. Saratsis, P.; Alexopoulos, C.; Tzora, A.; Fthenakis, G.C. The effect of experimentally induced subclinical mastitis on the milk yield of dairy ewes. Small Rumin. Res. 1999, 32, 205-209. [CrossRef]

34. Gonzalo, C.; Carriedo, J.A.; Blanco, M.A.; Beneitez, E.; Juárez, M.T.; De La Fuente, L.F.; San Primitivo, F. Factors of variation influencing bulk tank somatic cell count in dairy sheep. J. Dairy Sci. 2005, 88, 969-974. [CrossRef] 
35. Griffiths, K.J.; Ridler, A.L.; Compton, C.W.R.; Corner-Thomas, R.A.; Kenyon, P.R. Associations between lamb growth to weaning and dam udder and teat scores. N. Z. Vet. J. 2019, 67, 172-179. [CrossRef] [PubMed]

36. Flay, K.J.; Ridler, A.L.; Kenyon, P.R. Palpable udder defects are associated with decreased lamb production in commercial ewes. Livest. Sci. 2020, 242, 104316. [CrossRef]

37. Peterson, S.W.; Mackenzie, D.D.S.; McCutcheon, S.N.; Lapwood, K.R. Long-term bromocriptine treatment during late pregnancy has differential effects on milk yields of single- and twin-bearing ewes. N. Z. J. Agric. Res. 1997, 40, 249-259. [CrossRef]

38. Van der Linden, D.S.; Kenyon, P.R.; Jenkinson, C.M.C.; Peterson, S.W.; Blair, H.T. Carry-over effects of ewe nutrition and birth rank during the previous pregnancy on the milking performance during the subsequent lactation of Romney ewes. Anim. Prod. Sci. 2011, 51, 102-110. [CrossRef]

39. R Core Team. R: A Language and Environment for Statistical Computing; R Foundation for Statistical Computing: Vienna, Austria, 2020.

40. Dalton, D.C.; Knight, T.W.; Johnson, D.L. Lamb survival in sheep breeds on New Zealand hill country. N. Z. J. Agric. Res. 1980, 23, 167-173. [CrossRef]

41. Morris, S.T.; Kenyon, P.R. Intensive sheep and beef production from pasture-A New Zealand perspective of concerns, opportunities and challenges. Meat Sci. 2014, 98, 330-335. [CrossRef]

42. Bergonier, D.; Berthelot, X. New advances in epizootiology and control of ewe mastitis. Livest. Prod. Sci. 2003, 79, 1-16. [CrossRef]

43. Quinlivan, T. Survey observations on ovine mastitis in New Zealand stud Romney flocks: 2. The bacteriology of ovine mastitis. N. Z. Vet. J. 1968, 16, 153-160. [CrossRef]

44. Pulina, G.; Rassu, S.; Cannas, A. The effect of group feeding strategy on milk production in dairy ewes. Atti. Della Soc. Ital. Delle Sci. Vet. 1993. Available online: https:/ / agris.fao.org/agris-search/search.do?recordID=IT9562238 (accessed on 18 July 2021).

45. Peterson, S.; PCH, M.; PR, K.; ST, M. Milk production in Romney ewes lambing out of season. In Proceedings of the New Zealand Society of Animal Production, Napier, New Zealand, 24-26 January 2006; pp. 450-455.

46. Murphy, T.W.; Stewart, W.C.; Taylor, J.B. Factors affecting ewe somatic cell count and its relationship with lamb weaning weight in extensively managed flocks1. Transl. Anim. Sci. 2018, 2, S159-S162. [CrossRef]

47. Zafalon, L.F.; Júnior, G.A.F.; Vaso, C.O.; Lopes, N.S.S.; Veschi, J.L.A.; Santana, R.C.M. Influence of lactation stages and rain periods on subclinical mastitis in meat producing ewes. Cienc. Rural. 2016, 46, 1797-1803. [CrossRef]

48. Cheng, A.G.; DeDent, A.C.; Schneewind, O.; Missiakas, D. A play in four acts: Staphylococcus aureus abscess formation. Trends Microbiol 2011, 19, 225-232. [CrossRef]

49. Leitner, G.; Merin, U.; Silanikove, N. Effects of glandular bacterial infection and stage of lactation on milk clotting parameters: Comparison among cows, goats and sheep. Int. Dairy J. 2011, 21, 279-285. [CrossRef]

50. Rovai, M.; Caja, G.; Salama, A.A.K.; Jubert, A.; Lázaro, B.; Lázaro, M.; Leitner, G. Identifying the major bacteria causing intramammary infections in individual milk samples of sheep and goats using traditional bacteria culturing and real-time polymerase chain reaction. J. Dairy Sci. 2014, 97, 5393-5400. [CrossRef] [PubMed]

51. Malek dos Reis, C.B.; Barreiro, J.R.; Mestieri, L.; Porcionato, M.A.d.F.; dos Santos, M.V. Effect of somatic cell count and mastitis pathogens on milk composition in Gyr cows. BMC Vet. Res. 2013, 9, 67. [CrossRef]

52. Geenty, K.G. Lactation performance, growth, and carcass composition of sheep. N. Z. J. Agric. Res. 1979, 22, 241-250. [CrossRef]

53. Danso, A.S.; Morel, P.C.; Kenyon, P.R.; Blair, H.T. Relationships between prenatal ewe traits, milk production, and preweaning performance of twin lambs. J. Anim. Sci. 2016, 94, 3527-3539. [CrossRef] [PubMed] 